\title{
A review of Propulsion Industrial Base Studies and an Introduction to the National Institute of Rocket Propulsion Systems
}

\author{
Rajiv Doreswamy ${ }^{1}$, Ph.D. and Emma K. Fry ${ }^{2}$ \\ NASA Marshall Space Flight Center Huntsville, AL 35812
}

\begin{abstract}
Over the past decade there have been over 40 studies that have examined the state of the industrial base and infrastructure that supports propulsion systems development in the United States. This paper offers a comprehensive, systematic review of these studies and develops conclusions and recommendations in the areas of budget, policy, sustainment, infrastructure, workforce retention and development and mission/vision and policy. The National Institute for Rocket Propulsion System (NIRPS) is a coordinated, national organization that is responding to the key issues highlighted in these studies. The paper outlines the case for NIRPS and the specific actions that the Institute is taking to address these issues.
\end{abstract}

\section{Introduction}

$\mathrm{O}$ ver the past decade, numerous studies have pointed out the decline of the U.S. propulsion industrial base. In recent years, the Space Shuttle Program ended and the Constellation Program, which was slated to be the next human- rated space transportation system, was cancelled. Additionally, projections made in the early 2000's, for the size of the commercial launch market have not been realized. While the Federal Aviation Administration still projects a sizeable commercial market and NASA policy encourages development through the Commercial Orbital Transportation Services (COTS) and Commercial Crew Development (CCDEV) programs, these programs are aimed primarily at new entrants to the market rather than the traditional propulsion industrial base. These factors, along with a lack of new development programs initiated by the U.S. Government, increased foreign competition, and an aging workforce both in government and industry, have each contributed to the decline of the propulsion industrial base.

The propulsion industrial base provides capabilities and technologies that are critical to the defense and economic well being of the United States. Propulsion enables access to space for defense and intelligence purposes as well as for earth observation, weather and space weather forecasting, communications and navigation, and numerous other uses. Propulsion also provides the DoD the means to deliver payloads to targets for both strategic and tactical purposes. The loss of these critical technologies would have a seriously adverse effect on U.S. defense capabilities, space exploration potential, and economic health.

With these critical needs in mind, NASA serves as the founding partner of the National Institute for Rocket Propulsion Systems (NIRPS). NIRPS is partnership between NASA, other federal government agencies, industry and academia. NIRPS will support the preservation and advancement of the nation's rocket propulsion base to ensure its vital role in national security, space exploration, economic growth, and education. NIRPS will serve as policy steward, technology integrator, and solutions facilitator to reverse erosion and strengthen the global competitiveness of the U.S. propulsion base.

\footnotetext{
${ }^{1}$ Stewardship Facilitator, National Institute for Rocket Propulsion System, FP40, NASA/MSFC

${ }^{2}$ Graduate Student Co-op, Office of Strategic Analysis and Communication, MSFC-CS10, and AIAA Student Member.
} 


\section{Background}

Over the course of the last four decades the number of active rocket engine developments steadily decreased, with small peaks when a new system was developed, as shown in Fig 1.

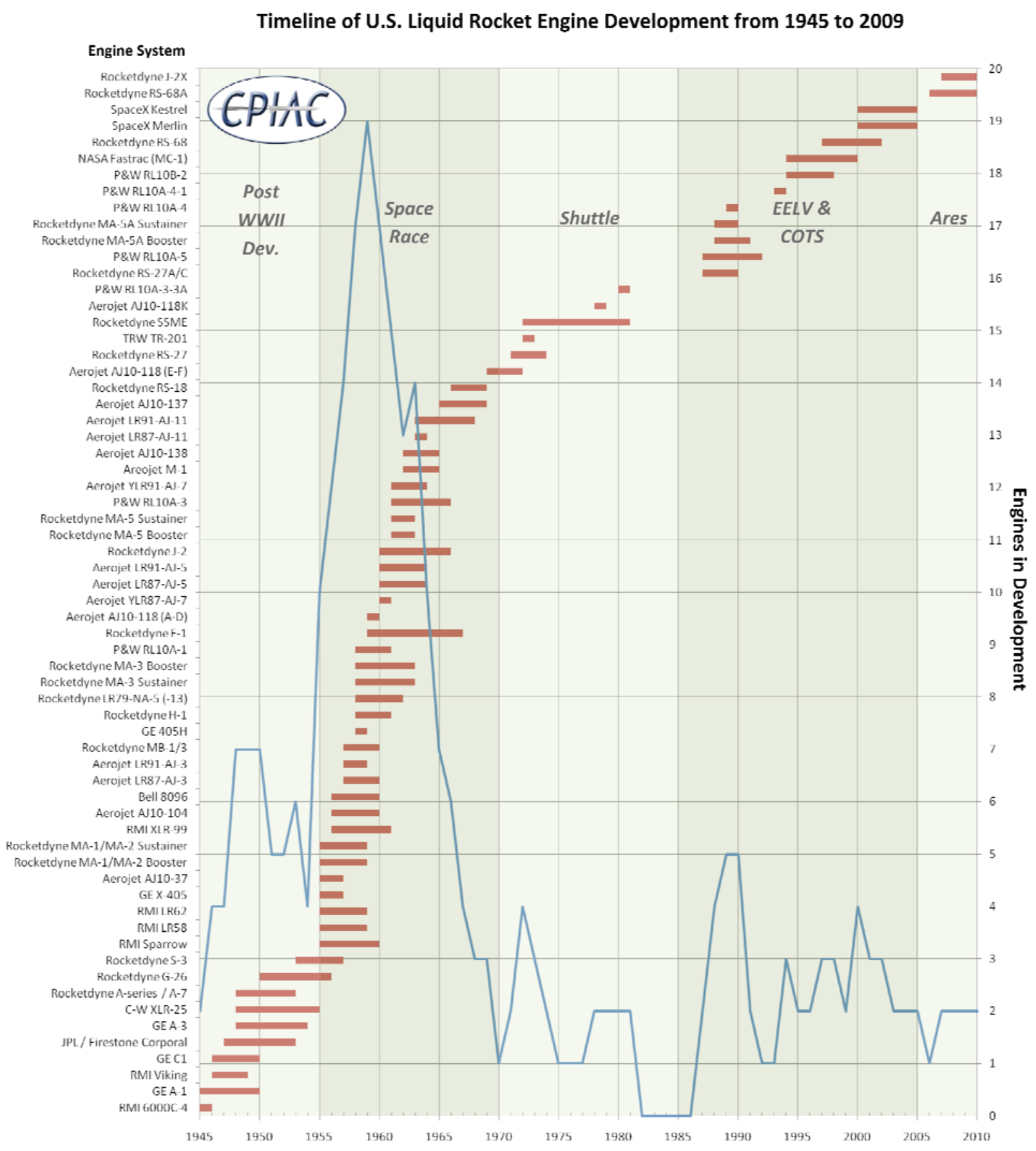

Fig. 1. Rocket engine development 1945-2009.

American Institute of Aeronautics and Astronautics 
Fig. 2 shows the decline in solid rocket motor development over the same time period.

Timeline of U.S. Solid Rocket Motor Development from 1945 to 2009

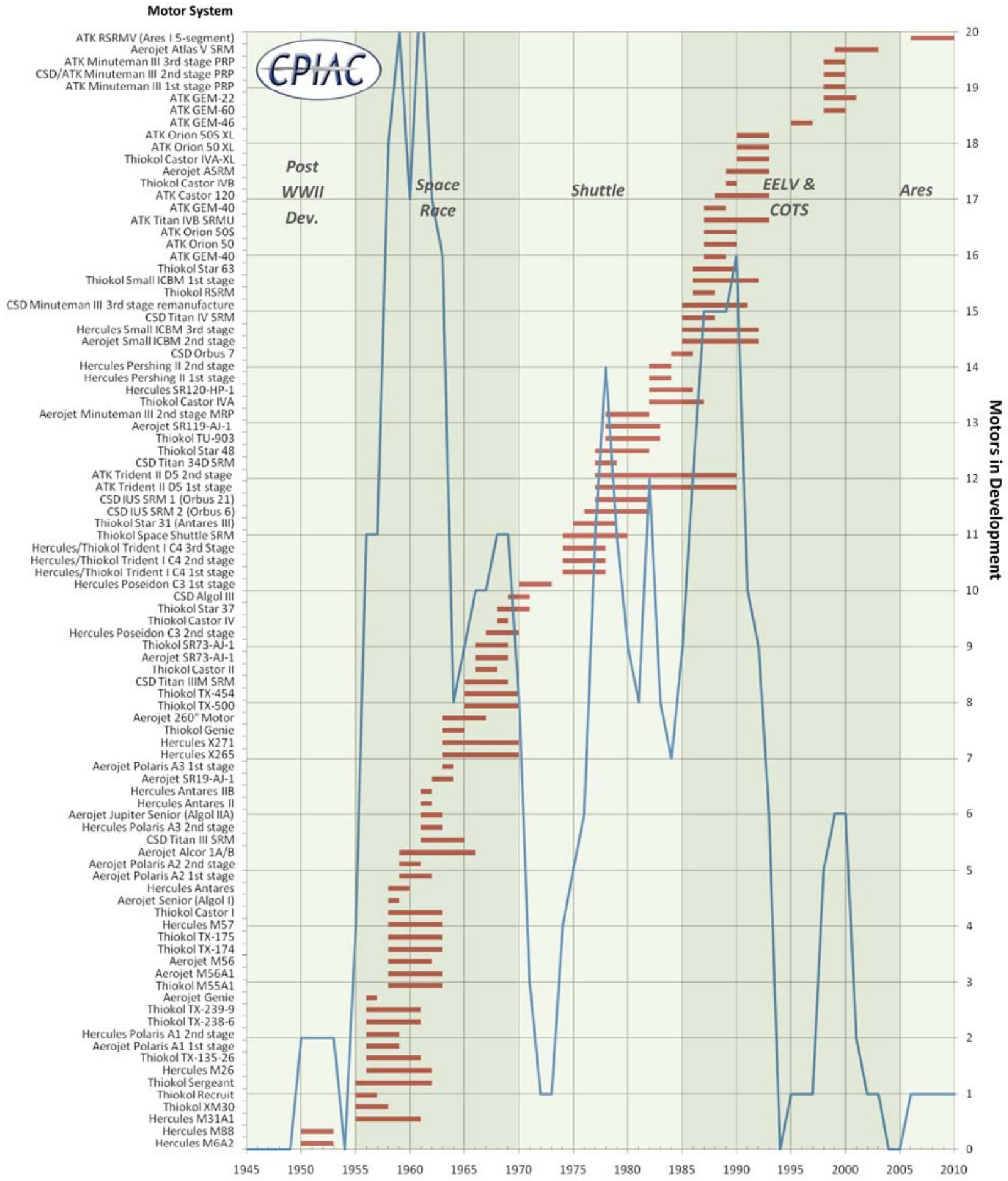

Fig. 2. Solid rocket motor development 1945-2009

With the end of the Space Shuttle Program and the cancellation of the Constellation program, there will be few opportunities for new rocket engine and solid rocket motor developments funded by the federal government. This 
lack of new development has profoundly affected the industrial base, resulting in consolidation of the contractor community and the phase-out or closure of test and R\&D facilities in the government sector. The aging of the propulsion workforce (both engineering and skilled labor) over the past few decades resulted in fewer people with the skills and expertise to develop new propulsion systems. A marked increase in the number of launches of foreign developed launch vehicles and the entry of China and India into the launch vehicle market has also occurred during this time.

\section{Propulsion Industrial Base Studies}

\begin{tabular}{|c|}
\hline Public Release Studies \\
\hline National Security Space Strategy ${ }^{1}$ \\
\hline National Space Policy ${ }^{2}$ \\
\hline NASA Authorization $\mathrm{Act}^{3}$ \\
\hline Maser Testimony to Congress ${ }^{4}$ \\
\hline Annual Industrial Capabilities Report ${ }^{5}$ \\
\hline Letter on Space Launch Propulsion ${ }^{6}$ \\
\hline $\begin{array}{l}\text { Report of the SRM Industrial Capabilities } \\
\text { Report to Congress }\end{array}$ \\
\hline $\begin{array}{l}\text { Reversing Industrial Decline: A Role for the } \\
\text { Defense Budget }^{8}\end{array}$ \\
\hline 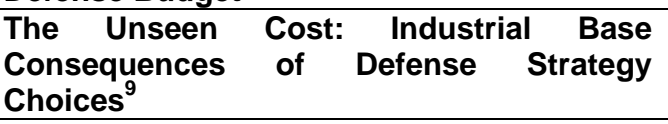 \\
\hline $\begin{array}{l}\text { Leadership, Management, and Organization } \\
\text { for National Security Space }\end{array}$ \\
\hline $\begin{array}{l}\text { Department Wide Framework to Identify } \\
\text { and Report Gaps in Defense Supplier } \\
\text { Base }^{11}\end{array}$ \\
\hline $\begin{array}{l}\text { Creating an Effective National Security } \\
\text { Industrial Base for the } 21^{\text {st }} \text { Century }\end{array}$ \\
\hline $\begin{array}{l}\text { Health of the US Space Industrial Base and } \\
\text { the Impact of Export Controls }\end{array}$ \\
\hline US Space Industrial Base Assessment $^{14}$ \\
\hline $\begin{array}{l}\text { National Security Space Industrial Base } \\
\text { Study }\end{array}$ \\
\hline Space Acquisitions ${ }^{16}$ \\
\hline Advanced Propulsion Study ${ }^{17}$ \\
\hline $\begin{array}{l}\text { Acquisition of National Security Space } \\
\text { Programs }^{18}\end{array}$ \\
\hline Year End Review ${ }^{19}$ \\
\hline Competition and Innovation (RAND) $^{2}$ \\
\hline
\end{tabular}

A joint NASA/Industry/Academic team reviewed a total of 44 studies performed by government, academic, and private sector organizations since 2000 that addressed the state of the propulsion industrial base and provided suggestions to address the perceived problems. These studies took two primary forms. The first type of study included publically released and non-categorized studies that addressed the propulsion or space industrial base as well as the government and academic infrastructure that supported the industrial base as customers or sources of skilled workers for the industry. The second form of study included a series of reports that were categorized "for official government use only" or as containing sensitive or proprietary data. The NIRPS team developed a systematic method to review and analyze these studies.

To ensure a complete and thorough review, a two-step process was implemented. First, the publically available studies were analyzed. Three team members, consisting of at least one government and one industry partner, evaluated each report. These teams reviewed each report and developed a one-page summary outlining the key points and identifying areas where NIRPS could make a contribution to affect the problem. Second, a NIRPS staff member analyzed the results and using a standard template, developed a one-page analysis sheet that summarized key findings and recommendations. This analysis grouped the report's conclusions by impact themes including: budget, policy, sustainment, mission/vision, infrastructure and workforce. The analysis also developed specific actions for NIRPS to address the findings. The studies used in phase 1 are shown in Fig. 3.

\section{Fig. 3. Public Release Studies}

The restricted studies followed a similar process, with the exception that all reviewers were US government employees. These studies included specific recommendations regarding acquisition strategies; make vs. buy decisions, and policy recommendations that limited their review to US personnel only. The overall conclusions were shared with the NIRPS team.

The following review forms (Fig.4) were used as a template by all of the document reviewers, ensuring consistency in the summary reviews of each study. 


\section{Document Review Form}

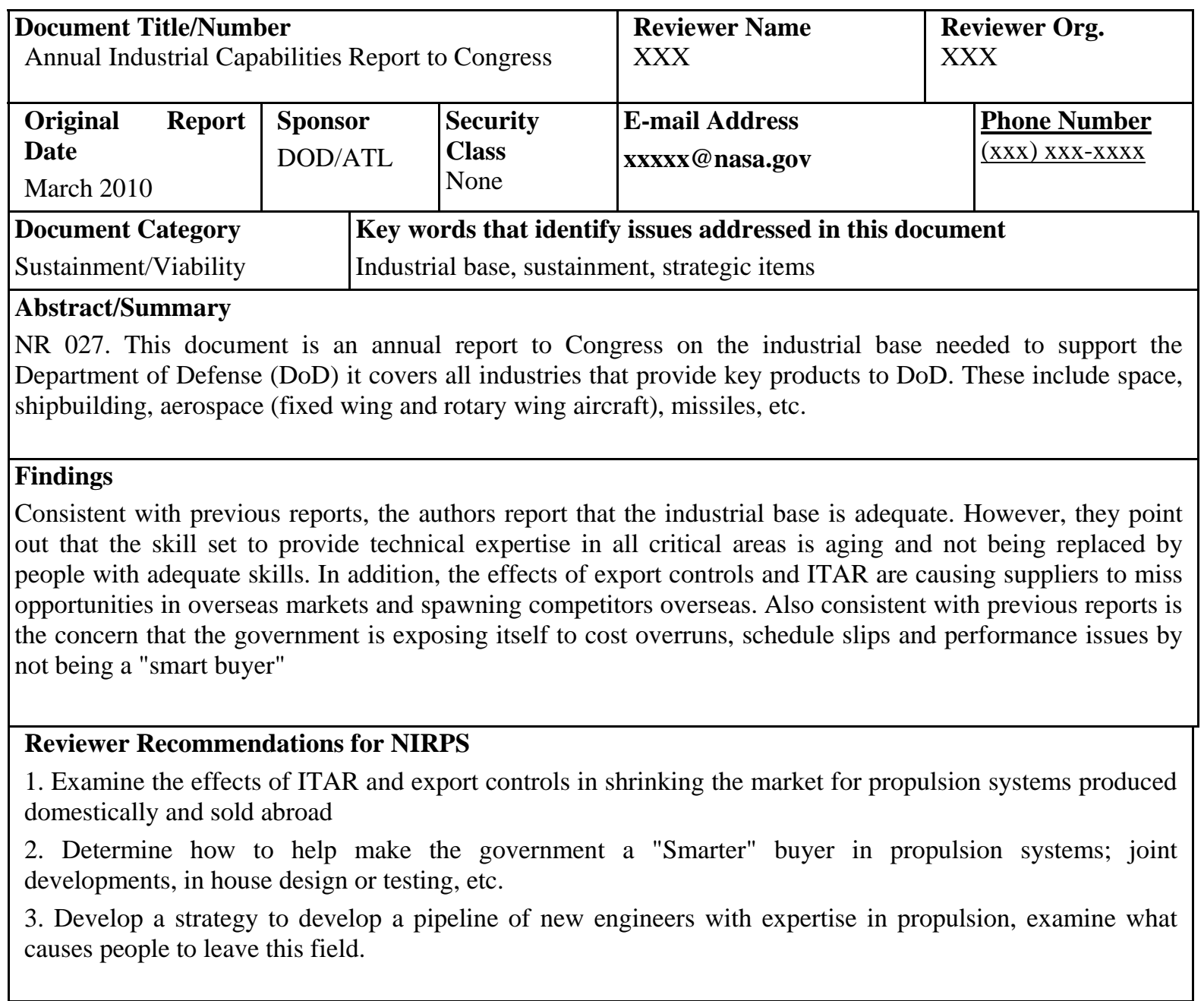

Fig. 4 provides a sample of the summary sheet.

The Document Assessment Sheet is reproduced below in Fig. 5 and serves as a summary and action recommendation for each report. 
NIRPS Internal Assessment

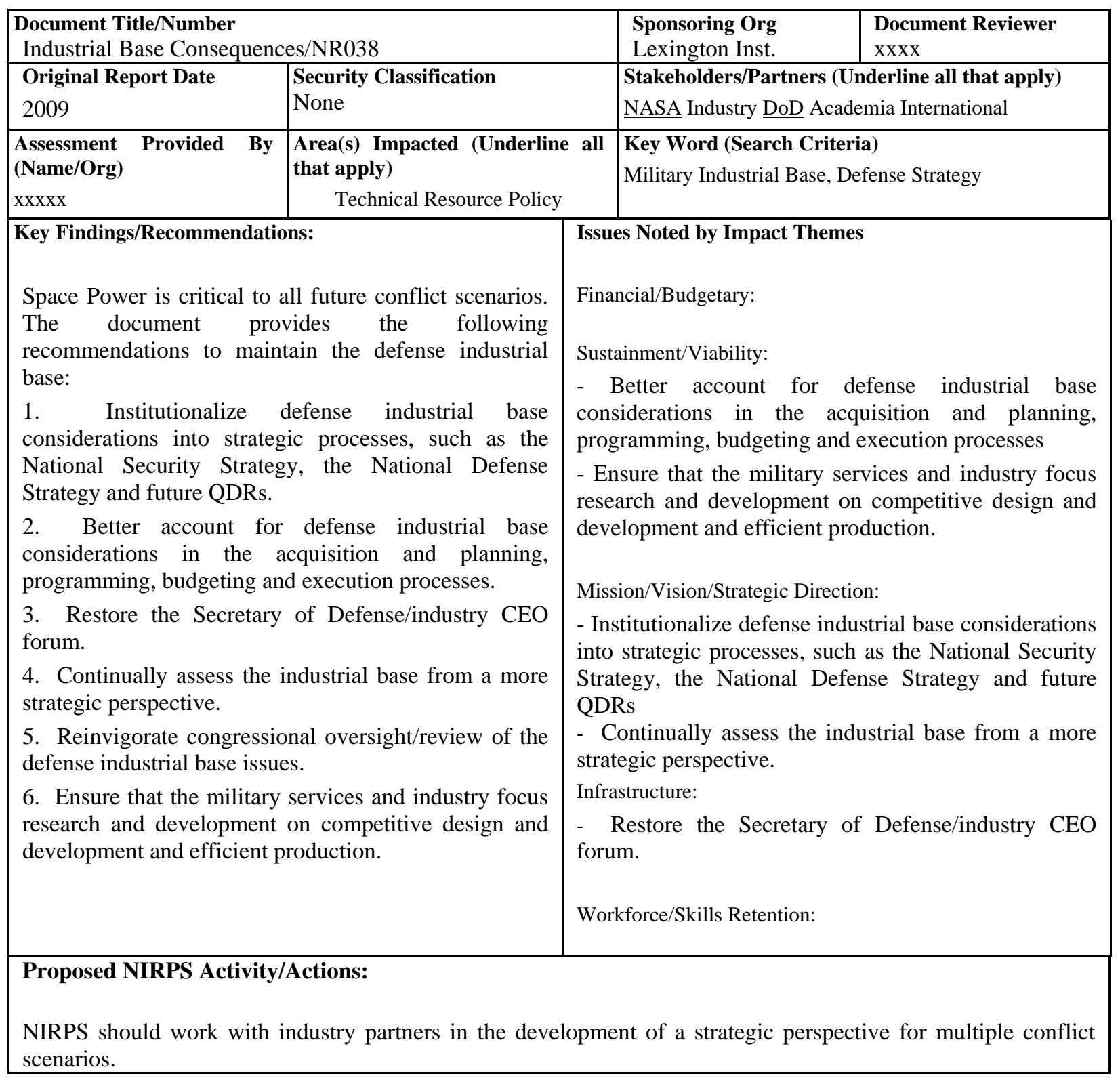

Fig. 5. NIRPS Document Assessment Sheet 


\section{Results}

For NIRPS to be effective, it must address the significant and recurring issues that are affecting the entire propulsion ecosystem. The first step in addressing these problems was to identify the recurring themes that were cited by the numerous propulsion industrial base studies reviewed. These themes included policy related issues including a lack of integrated space strategies across government agencies and departments, a lack of a multi-agency vision, a lack of defined space missions, as well as a lack of predictable long term funding.

Additionally, programmatic issues were a common theme. These included frequent program starts and cancellations, in particular the Shuttle retirement leading to an uncertainty in future needs and to the industrial base decline. This lead further to an overcapacity of production capability and rising supplier costs. Of particular note was the large solid rocket motor industrial base decline. When coupled with the difficulty in access to government facilities, this lead to systems infrastructure, supply chain, and skill base challenges. This ultimately has resulted in a general loss of competitiveness for the propulsion community in the global market.

Similarly, there were common themes in the studies that identified workforce related issues stemming from the aforementioned policy issues. The aging work force coupled with a lack of sustained technology development resulted in fewer engineers with the necessary technology development experience. This, added with an overall decline in aerospace engineer demand, also further exacerbated the loss of competitiveness for the propulsion community in the global market.

A two-step process was implemented to begin addressing these common themes. First, the NIRPS team held a strategy meeting with representatives from NASA, DoD, industry, academia and others to discuss the study reviews. In this session, some common key needs to address the themes emerged. These needs were then refined into the NIRPS “Grand Challenges”.

Key needs identified:

1) Competiveness and resilience of the propulsion industrial base

2) An integrated science and technology plan

3) Better collaboration across agencies for propulsion systems development

4) Better and easier access to government facilities and expertise

5) Revitalized Science, Technology, Engineering and Mathematics (STEM) pipeline

6) Reduction of development and sustainment cost for propulsion components and systems

The Grand Challenges are:

1) Reduce development and sustainment costs for missile and rocket systems

2) Support the competitiveness and resilience of the industrial base

3) Foster access to facilities and expertise across government, industry, and academia

4) Develop and implement an integrated science and technology plan for propulsion systems

5) Invigorate the Science, Technology, Engineering and Mathematics (STEM) pipeline

6) Collaborate across agencies for missile and rocket propulsion system development.

While some of the results of the industrial base studies were well known and anticipated, the studies show that the NIRPS Grand Challenges are effective in describing the problems facing the propulsion industry and in providing a path for resolution.

Fig. 6 below clearly shows that all of the major conclusions of the group of studies are addressed by the NIRPS Grand Challenges. The major task of NIRPS is to build an organization that will develop and implement strategies to address the issues confronting the propulsion industry. The strategies must be achievable, cost effective, and sustainable. Additionally, NIRPS must be representative of the entire propulsion ecosystem (providers, customers, and other stakeholders), and be effective in both developing solutions to these issues, as well as advocating for an effective response with stakeholders and decision makers. 


\begin{tabular}{|c|c|c|c|c|c|c|}
\hline Study Conclusion & $\mathrm{GC1}$ & $\mathrm{GC2}$ & GC3 & GC4 & GC5 & GC6 \\
\hline & $\begin{array}{l}\text { Reduce } \\
\text { development and } \\
\text { sustainment } \\
\text { costs for missile } \\
\text { and rocket } \\
\text { systems }\end{array}$ & \begin{tabular}{|l|} 
Support the \\
competitiveness \\
and resilience of \\
the industrial \\
base
\end{tabular} & $\begin{array}{l}\text { Foster access } \\
\text { to facilities } \\
\text { and expertise } \\
\text { across } \\
\text { government, } \\
\text { industry, and } \\
\text { academia } \\
\end{array}$ & $\begin{array}{l}\text { Develop and } \\
\text { implement an } \\
\text { integrated } \\
\text { science and } \\
\text { technology plan } \\
\text { for propulsion } \\
\text { systems }\end{array}$ & $\begin{array}{l}\text { Invigorate the STEM } \\
\text { Pipeline to Grow } \\
\text { Propulsion Systems } \\
\text { Expertise. }\end{array}$ & $\begin{array}{l}\text { Collaborate across } \\
\text { agencies for } \\
\text { missile and rocket } \\
\text { propulsion system } \\
\text { development. } \\
\end{array}$ \\
\hline Increased Foreign Competition & $\mathrm{P}$ & $\mathrm{P}$ & $\mathrm{S}$ & & $\mathrm{S}$ & \\
\hline $\begin{array}{r}\text { Large decline in business base } \\
\text { for solid rocket motors }\end{array}$ & P & $\mathrm{P}$ & & S & & $P$ \\
\hline $\begin{array}{r}\text { US competiveness in the global } \\
\text { market must be improved for a } \\
\text { viable industry }\end{array}$ & P & $\mathrm{P}$ & S & & S & $P$ \\
\hline $\begin{array}{r}\text { Lower budgets in the US for } \\
\text { operations as well as research } \\
\text { and development has led to } \\
\text { market uncertainty }\end{array}$ & $P$ & $\mathrm{P}$ & P & P & & $P$ \\
\hline $\begin{array}{r}\text { USG acquisition process needs } \\
\text { to be updated to lower overall } \\
\text { program cost and to efficiently } \\
\text { deploy funds }\end{array}$ & P & $\mathrm{P}$ & & & & P \\
\hline $\begin{array}{r}\text { R\&D and Technology budgets } \\
\text { have not kept up with strategic } \\
\text { needs }\end{array}$ & $P$ & & & P & $P$ & $P$ \\
\hline $\begin{array}{r}\text { A healthy viable propulsion } \\
\text { Industrial base is required for } \\
\text { US national Security and } \\
\text { economic competitiveness }\end{array}$ & $P$ & P & P & P & $P$ & $P$ \\
\hline $\begin{array}{r}\text { Reform of Export Controls, } \\
\text { allowing for security, as well as } \\
\text { cooperation \& enlargement of } \\
\text { markets will contribute to } \\
\text { lowering costs as well as } \\
\text { maintaining the industrial base. }\end{array}$ & P & P & & & & \\
\hline $\begin{array}{r}\text { Reenergizing the industrial } \\
\text { base \& sustaining it by } \\
\text { developing new technology, } \\
\text { lowering cost \& helping to } \\
\text { develop the next generation } \\
\text { workforce }\end{array}$ & P & $\mathrm{P}$ & $\mathrm{S}$ & S & $P$ & S \\
\hline $\begin{array}{r}\text { Access to US Government } \\
\text { facilities and expertise needs to } \\
\text { be streamlined }\end{array}$ & & & P & P & & $P$ \\
\hline $\begin{array}{r}\text { Rising supplier cost as well as } \\
\text { a shrinking supplier base have } \\
\text { contributed to the increase in } \\
\text { launch costs }\end{array}$ & $P$ & P & & & & \\
\hline $\begin{array}{r}\text { Many critical components and } \\
\text { materials are now single } \\
\text { domestic source or foreign } \\
\text { source only }\end{array}$ & $P$ & P & & P & & \\
\hline $\begin{array}{r}\text { Impacts of the end of Shuttle } \\
\text { and cancellation of } \\
\text { Constellation have not been } \\
\text { quantified }\end{array}$ & $P$ & P & & P & $\mathrm{S}$ & P \\
\hline $\begin{array}{r}\text { Fewer engineer have } \\
\text { experience in propulsion } \\
\text { systems development }\end{array}$ & $P$ & $\mathrm{P}$ & & $\mathrm{P}$ & & \\
\hline $\begin{array}{r}\text { Improvement of capabilities } \\
\text { and renewal of the workforce is } \\
\text { needed to maintain US } \\
\text { capabilities }\end{array}$ & $P$ & P & $\mathrm{P}$ & & P & \\
\hline $\begin{array}{r}\text { An active strategy in needed to } \\
\text { encourage students to enter } \\
\text { propulsion related fields }\end{array}$ & & & & P & $P$ & \\
\hline $\begin{array}{r}\text { Skilled labor capabilities are } \\
\text { also facing decline and will } \\
\text { need renewal }\end{array}$ & & & & & P & \\
\hline $\begin{array}{r}\text { Outside of the propulsion } \\
\text { community, policy/decision } \\
\text { makers perceive more } \\
\text { coordination between NASA } \\
\text { and DoD than currently exists }\end{array}$ & & & P & $\mathrm{P}$ & & P \\
\hline $\begin{array}{r}\text { There exists a critical need for } \\
\text { collaboration and coordination } \\
\text { between Agencies of the US } \\
\text { Government }\end{array}$ & & & P & $\mathrm{P}$ & & P \\
\hline
\end{tabular}

Fig. 6 shows the Grand Challenges mapped against the study findings (P-primary, S-secondary). 


\section{NIRPS as a Response to the Grand Challenges}

\section{A. NIRPS Overview}

NIRPS is an organization that is government-led, using a multi-agency model. A board of directors will govern the Institute with representation from multiple government agencies, and with the National Aeronautics and Space Administration (NASA) serving as the host agency. NIRPS will be managed by a Director and Deputy Director, who are senior executives (or equivalent) in the US Government. The Board will be advised by an industry and academic forum, which will ensure that NIRPS is responsive to the needs of the entire propulsion community.

\section{B. NIRPS Teams and Strategies}

NIRPS formed three strategy teams to work the challenges identified by the studies, recognizing that many of them overlap to a degree. The three teams include a Stewardship, Technology and Solutions Facilitator team. There is also a crosscutting forum to communicate, exchange ideas, identify overlapping opportunities and approaches, and look for inconsistencies.

The Stewardship Team has developed five strategies and twenty objectives within those five strategies. The Stewardship Team will focus on the strategies to define a healthy industrial base and create and implement a roadmap to achieve a unified DoD/NASA policy regarding maintaining a healthy industrial base. To define a healthy industrial base, the team is developing metrics to understand the ramifications of a declining industrial base on the ability to maintain DoD and NASA programs. The team will also measure the ability of industry to react to and support sudden needs for rocket propulsion systems. Additional strategies include developing and promulgating options to improve U.S. competitiveness, promoting best value approaches, and suggesting methods to increase STEM degrees applicable to propulsion careers.

The Technology Team has developed four strategies with one still in development. There will be about nineteen objectives within those strategies. The current Technology Team strategies include improving the visibility of propulsion-related STEM opportunities, providing visibility of advance propulsion work and technologies, developing and implementing a science and technology plan to facilitate national efforts, and identifying methods for facilitating the transition of technology to flight and practical applications. These last two strategies are key focus areas. For example, under developing and implementing a science and technology plan, one objective will require a prioritization of propulsion technologies for the U.S. One proposed product is similar to the National Research Council's Decadal Survey that is performed every 10 years for the Science community. The Technology Team would provide a similar product to prioritize what propulsion technologies warrant putting time, dollars, and effort into developing.

The Solutions Facilitator Team has four strategies with ten objectives and more currently in development. Those strategies include: communicating skills and capabilities, communicating projects and activities, streamlining facilitation mechanisms, and providing skills and capabilities assessment. A top priority of the Solutions Facilitator Team will be providing streamlined facilitation mechanism for interactions between members of the entire propulsion community. Objectives include simplifying access to government skills, facilitating collaboration across government agencies and non-government partners, and investigating a government-funded pool for quick starts and small, short-duration activities. 
The relationships of the NIRPS teams to each of the Grand Challenges are shown in Fig. 7.

\section{Inter-relationships of Grand Challenges}

\begin{tabular}{|l|c|c|c|}
\hline \multicolumn{1}{|c|}{ Grand Challenge } & Stewardship & Technology & $\begin{array}{c}\text { Solutions } \\
\text { Facilitator }\end{array}$ \\
\hline $\begin{array}{l}\text { Support the competitiveness and } \\
\text { resilience of the industrial base }\end{array}$ & Primary & Secondary & Secondary \\
\hline $\begin{array}{l}\text { Invigorate the STEM pipeline to } \\
\text { Grow Propulsion Systems Expertise }\end{array}$ & Primary & Secondary & Secondary \\
\hline $\begin{array}{l}\text { Develop and implement an } \\
\text { integrated science \& technology } \\
\text { plan for propulsion systems }\end{array}$ & Secondary & Primary & Secondary \\
\hline $\begin{array}{l}\text { Reduce development and } \\
\text { sustainment costs for missile and } \\
\text { rocket systems }\end{array}$ & Secondary & Primary & Secondary \\
\hline $\begin{array}{l}\text { Collaborate across agencies for } \\
\text { missile and rocket propulsion } \\
\text { system development }\end{array}$ & Secondary & Secondary \\
\hline $\begin{array}{l}\text { Foster access to facilities and } \\
\text { expertise across Government, } \\
\text { industry, and academia }\end{array}$ & Secondary & Secondary & Primary \\
\hline
\end{tabular}

\section{NRPS}

\section{Fig. 7. NIRPS Grand Challenges Allocation to Strategy Teams}

The teams are the action agents for NIRPS and have representation from academia, industry, and government organizations. Each of the teams has developed strategies and objectives, mentioned previously, to address each of the Grand Challenges. This mapping is shown in Fig.8. 


\begin{tabular}{|c|c|c|c|c|c|c|c|}
\hline \multirow[b]{2}{*}{ Team } & \multirow[b]{2}{*}{ Strategy } & \multicolumn{6}{|c|}{ Grand Challenges } \\
\hline & & $\begin{array}{l}\text { GC1. Support } \\
\text { the } \\
\text { competitive- } \\
\text { ness and } \\
\text { resilience of } \\
\text { the industrial } \\
\text { base. }\end{array}$ & $\begin{array}{l}\text { GC2. } \\
\text { Invigorate the } \\
\text { STEM pipeline } \\
\text { to Grow } \\
\text { Propulsion } \\
\text { Systems } \\
\text { Expertise. }\end{array}$ & $\begin{array}{l}\text { GC3. Develop } \\
\text { \& implement } \\
\text { an integrated } \\
\text { science \& } \\
\text { technology } \\
\text { plan for prop. } \\
\text { Systems. }\end{array}$ & $\begin{array}{l}\text { GC4. Reduce } \\
\text { development \& } \\
\text { sustainment } \\
\text { costs for } \\
\text { missiles and } \\
\text { rocket systems }\end{array}$ & $\begin{array}{l}\text { GC5. } \\
\text { Collaborate } \\
\text { across } \\
\text { Agencies for } \\
\text { missile \& } \\
\text { rocket } \\
\text { propulsion } \\
\text { system dev. }\end{array}$ & $\begin{array}{l}\text { GC6. Foster } \\
\text { access to } \\
\text { facilities \& } \\
\text { expertise } \\
\text { across gov't, } \\
\text { industry \& } \\
\text { academia. }\end{array}$ \\
\hline \multirow[t]{5}{*}{ Stewardship } & S1. Define a healthy industrial base. & Primary & Primary & Secondary & Primary & Primary & Secondary \\
\hline & $\begin{array}{l}\text { S2. Create and implement a roadmap to } \\
\text { achieve a unified US DoD/NASA policy } \\
\text { regarding maintaining a healthy industrial } \\
\text { base. }\end{array}$ & Primary & Secondary & Secondary & Primary & Primary & Secondary \\
\hline & $\begin{array}{l}\text { S3. Develop and implement options to } \\
\text { improve US competitiveness in rocket } \\
\text { propulsion systems. }\end{array}$ & Primary & Primary & Secondary & Secondary & Primary & Secondary \\
\hline & $\begin{array}{l}\text { S4. Promote acquisition strategies that } \\
\text { consider the National Propulsion Industrial } \\
\text { Goals }\end{array}$ & Secondary & Primary & Primary & Secondary & Primary & Secondary \\
\hline & $\begin{array}{l}\text { S5. Suggest methods to increase STEM } \\
\text { degrees applicable to RPS careers for US } \\
\text { citizens. }\end{array}$ & Secondary & Secondary & Primary & Secondary & Primary & Secondary \\
\hline \multirow[t]{4}{*}{ Technology } & $\begin{array}{l}\text { T1. Improve the visibility and broaden of } \\
\text { propulsion-related STEM opportunities to } \\
\text { the national audience. }\end{array}$ & Secondary & Secondary & Primary & Primary & Primary & Secondary \\
\hline & $\begin{array}{l}\text { T2. Provide visibility and coherence of } \\
\text { advanced propulsion work and } \\
\text { technologies to the national audience. }\end{array}$ & Secondary & N/A & Secondary & Primary & Secondary & N/A \\
\hline & $\begin{array}{l}\text { T3. Develop and implement a science and } \\
\text { technology roadmap to facilitate national } \\
\text { efforts. }\end{array}$ & Secondary & N/A & N/A & Primary & Primary & Primary \\
\hline & $\begin{array}{l}\text { T4. Identify methods for facilitating } \\
\text { transition of technology to flight and } \\
\text { practical applications. }\end{array}$ & Secondary & Secondary & Secondary & Secondary & Primary & Primary \\
\hline \multirow{4}{*}{$\begin{array}{l}\text { Solutions } \\
\text { Facilitator }\end{array}$} & $\begin{array}{l}\text { F1. Communicate and foster a broad } \\
\text { understanding of skills and capabilities } \\
\text { across the entire propulsion community. }\end{array}$ & Secondary & N/A & N/A & Primary & Primary & Primary \\
\hline & $\begin{array}{l}\text { F2. Communicate and foster a broad } \\
\text { understanding of projects and activities } \\
\text { across the entire propulsion community. }\end{array}$ & Secondary & Secondary & Secondary & Secondary & Primary & Primary \\
\hline & $\begin{array}{l}\text { F3. Provide streamlined facilitation } \\
\text { mechanisms for interactions between } \\
\text { members of the entire propulsion } \\
\text { community. }\end{array}$ & Secondary & Secondary & Secondary & Secondary & Primary & Primary \\
\hline & $\begin{array}{l}\text { F4. Provide periodic assessment of skills } \\
\text { and capabilities across the government } \\
\text { and propulsion community, and contrast } \\
\text { against projected requirements and need. }\end{array}$ & Secondary & Secondary & Secondary & Secondary & Secondary & Secondary \\
\hline
\end{tabular}

Fig. 8. NIRPS Strategies Mapping to Grand Challenges.

After the review and analysis of each propulsion and industrial base study, a core team met to determine the key points and actionable recommendations for NIRPS. These results were presented in two formats. One format mapped the common themes to each of the three strategy teams (Stewardship, Technology, and Solutions Facilitator) and the other format rolled up the key findings into six focus areas, derived from the six key needs previous identified. An example of mapping the findings to the teams is shown in Fig. 9, and mapping the findings to the six focus areas is shown in Fig. 10. 


\begin{tabular}{|c|c|c|c|}
\hline Source & Stewardship & Solutions Facilitator & Technology \\
\hline $\begin{array}{l}\text { National Security Space Strategy } \\
\text { (DoD, 2011) }\end{array}$ & $\begin{array}{l}\text { - Reform of Export Controls, } \\
\text { allowing for security, as well as } \\
\text { cooperation \& enlargement of } \\
\text { markets will contribute to } \\
\text { lowering costs as well as } \\
\text { maintaining the industrial base. } \\
\text { - Reenergizing the industrial } \\
\text { base \& sustaining it by } \\
\text { developing new technology, } \\
\text { lowering cost \& helping to } \\
\text { develop the next generation } \\
\text { workforce }\end{array}$ & $\begin{array}{l}\text { - Propulsion/Launch is a cost } \\
\text { that enables the mission but } \\
\text { does not execute it. Any } \\
\text { improvement in the cost/ } \\
\text { performance of this will enable } \\
\text { enhanced capabilities } \\
\text {-value }\end{array}$ & $\begin{array}{l}\text { - Improvement of capabilities to } \\
\text { are required to keep US lead in } \\
\text { National Security Space. This will } \\
\text { not happen w/o continued } \\
\text { development in technology, } \\
\text { lowering of costs \& } \\
\text { improvement in the health of } \\
\text { the Industry. }\end{array}$ \\
\hline $\begin{array}{l}\text { Creating an Effective National } \\
\text { Security Industrial Base for the } \\
\text { 21st Century (OSD ATL, 2008) }\end{array}$ & $\begin{array}{l}\text { - Provide recommendations to } \\
\text { DoD/NASA on how to incentivize } \\
\text { the space propulsion/launch } \\
\text { vehicle industry }\end{array}$ & $\begin{array}{l}\text { - Understand benefits of } \\
\text { internationals \& globalization }\end{array}$ & $\begin{array}{l}\text { - Make use of competitions } \\
\text { - Strengthen workforce }\end{array}$ \\
\hline $\begin{array}{l}\text { National Security Space Industrial } \\
\text { Base Study (OSD CAIG/ Thurman } \\
\text { Report,2006) }\end{array}$ & $\begin{array}{l}\text { - Guide \& advise in matters } \\
\text { regarding legacy systems; } \\
\text { i.e. .the balance between what } \\
\text { investments should be made in } \\
\text { sustaining versus innovating. } \\
\text { - Examine industrial base } \& \\
\text { develop sustainment plans }\end{array}$ & $\begin{array}{l}\text { - Provide educated advocacy of } \\
\text { National goals, needs, \& } \\
\text { objectives related to propulsion } \\
\text { systems, including prioritization } \\
\text { \& implementation approaches. }\end{array}$ & $\begin{array}{l}\text { - Provide guidance for } \\
\text { developing potential solution } \\
\text { scts for engaging/ attracting } \\
\text { young people to space } \\
\text { technologies. }\end{array}$ \\
\hline $\begin{array}{l}\text { Annual Industrial Capabilities } \\
\text { Report (OSD/ATL, 2009) }\end{array}$ & $\begin{array}{l}\text { - Explore the effects of ITAR } \\
\text { Policies \& Regulations and how } \\
\text { it impacts domestic } \\
\text { competitiveness }\end{array}$ & $\begin{array}{l}\text { - Participate in test assets survey } \\
\text { \& assessments } \\
\text { - Investigate the cost and } \\
\text { benefits of using commercial } \\
\text { technologies in propulsion } \\
\text { systems }\end{array}$ & $\begin{array}{l}\text { - Develop an international } \\
\text { technology \& partnership } \\
\text { strategy } \\
\text { - Develop a strategy to } \\
\text { encourage STEM participation at } \\
\text { the post high school level }\end{array}$ \\
\hline
\end{tabular}

\section{Fig. 9. Results mapped to the three strategy teams}

\begin{tabular}{|c|c|c|c|c|c|}
\hline Industrial Base & $\begin{array}{l}\text { Budget and } \\
\text { Acquisition }\end{array}$ & Policy & $\begin{array}{c}\text { Sustainment and } \\
\text { Viability }\end{array}$ & $\begin{array}{c}\text { Systems, } \\
\text { Infrastructure } \\
\text { and Skills }\end{array}$ & $\begin{array}{l}\text { Propulsion } \\
\text { Community } \\
\text { Coordination }\end{array}$ \\
\hline $\begin{array}{l}\text { US Propulsion } \\
\text { Industrial base is } \\
\text { viable, but } \\
\text { threatened } \\
\text { - Increased Foreign } \\
\text { Competition } \\
\text {-Lower than } \\
\text { anticipated launch } \\
\text { growth rates } \\
\text {-Large decline in } \\
\text { business base for } \\
\text { solid rocket motors } \\
\text {-US competiveness in } \\
\text { the global market } \\
\text { must be improved for } \\
\text { a viable industry }\end{array}$ & $\begin{array}{l}\text { Lower budgets in the } \\
\text { US for operations as } \\
\text { well as research and } \\
\text { development has led } \\
\text { to market uncertainty } \\
\text { USG acquisition } \\
\text { process needs to be } \\
\text { updated to lower } \\
\text { overall program cost } \\
\text { and to efficiently } \\
\text { deploy funds } \\
\text { R\&D and Technology } \\
\text { budgets have not } \\
\text { kept up with strategic } \\
\text { needs }\end{array}$ & $\begin{array}{l}\text { - A healthy viable } \\
\text { propulsion Industrial } \\
\text { base is required for } \\
\text { US national Security } \\
\text { and economic } \\
\text { competitiveness } \\
\text { - Reform of Export } \\
\text { Controls, allowing for } \\
\text { security, as well as } \\
\text { cooperation \& } \\
\text { enlargement of } \\
\text { markets will } \\
\text { contribute to } \\
\text { lowering costs as well } \\
\text { as maintaining the } \\
\text { industrial base. } \\
\text { - Reenergizing the } \\
\text { industrial base \& } \\
\text { sustaining it by } \\
\text { developing new } \\
\text { technology, lowering } \\
\text { cost \& helping to } \\
\text { develop the next } \\
\text { generation workforce } \\
\text {-Access to US } \\
\text { Government facilities } \\
\text { and expertise needs } \\
\text { to be streamlined }\end{array}$ & $\begin{array}{l}\text { - Rising supplier cost } \\
\text { as well as a shrinking } \\
\text { supplier base have } \\
\text { contributed to the } \\
\text { increase in launch } \\
\text { costs } \\
\text {-Many critical } \\
\text { components and } \\
\text { materials are now } \\
\text { single domestic } \\
\text { source or foreign } \\
\text { source only } \\
\text {-Impacts of the end } \\
\text { of Shuttle and } \\
\text { cancellation of } \\
\text { Constellation have } \\
\text { not been quantified }\end{array}$ & $\begin{array}{l}\text { - Fewer engineer have } \\
\text { experience in } \\
\text { propulsion systems } \\
\text { development } \\
\text {-Improvement of } \\
\text { capabilities and } \\
\text { renewal of the } \\
\text { workforce is needed } \\
\text { to maintain US } \\
\text { capabilities } \\
\text {-An active strategy in } \\
\text { needed to encourage } \\
\text { students to enter } \\
\text { propulsion related } \\
\text { fields } \\
\text {-Skilled labor } \\
\text { capabilities are also } \\
\text { facing decline and will } \\
\text { need renewal }\end{array}$ & $\begin{array}{l}\text { - Outside of the } \\
\text { propulsion } \\
\text { community, policy/ } \\
\text { decision makers } \\
\text { perceive more } \\
\text { coordination between } \\
\text { NASA and DoD than } \\
\text { currently exists } \\
\text { - There exists a } \\
\text { critical need for } \\
\text { collaboration and } \\
\text { coordination between } \\
\text { Agencies of the US } \\
\text { Government }\end{array}$ \\
\hline
\end{tabular}

Fig. 10. Results mapped to the six focus areas. 


\section{NIRPS as a Response to the Grand Challenges}

The challenges facing the propulsion industrial base are well known and several organizations have previously worked to address these issues. However, until the formation of NIRPS, there was not a coordinated effort to address all of the issues through one forum or program consisting of stakeholders from government, industry, and academia. Figure 11 below illustrates current and previous organizations and contributions to addressing the national needs facing the propulsion industrial base.
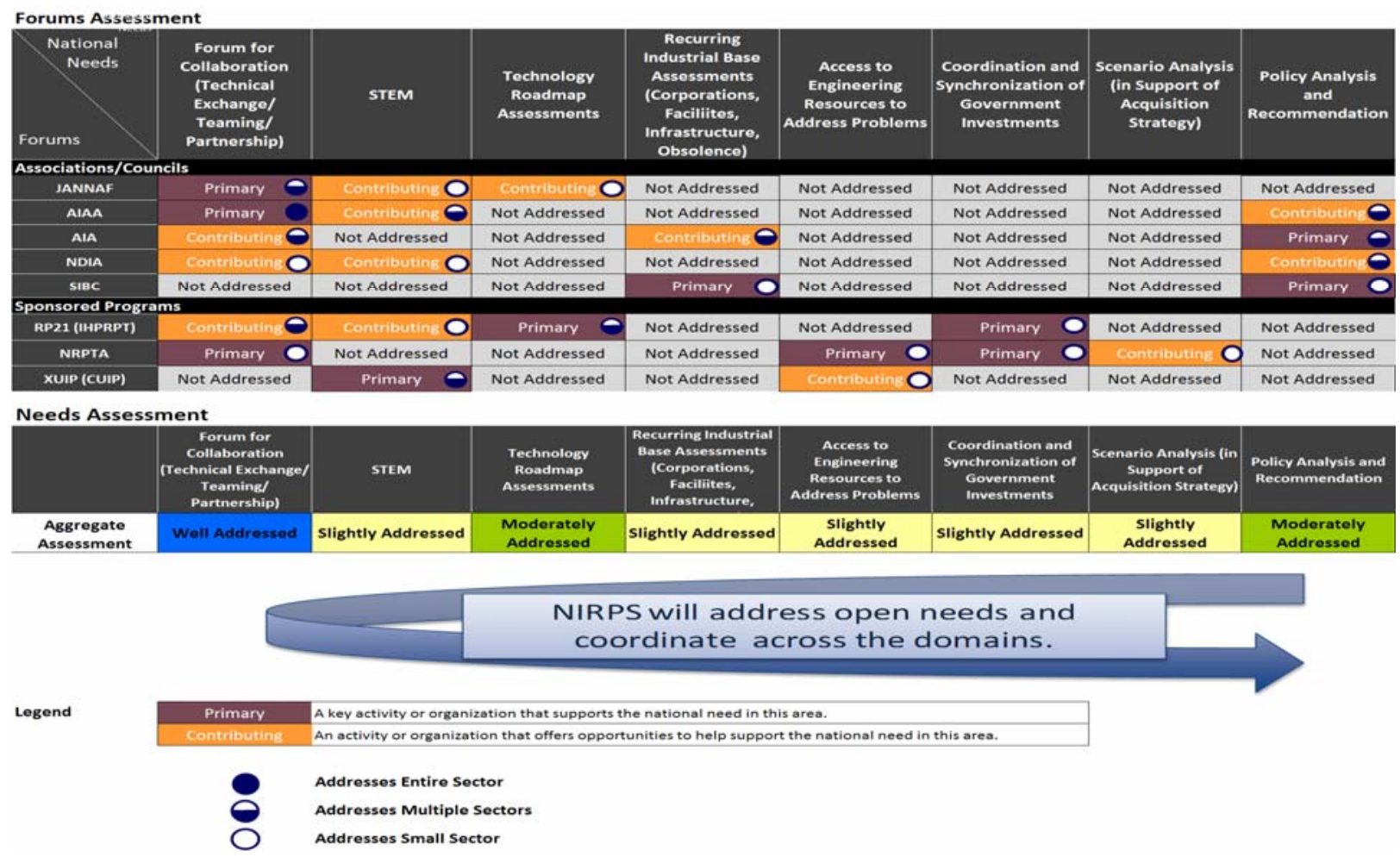

Fig. 11 Propulsion Forums and Needs Assessment

As Fig. 11 shows, only one national need has been well addressed. Through the three strategy teams NIRPS will work to address all open propulsion needs and coordinate actions across the domains. Given the number of issues needing to be addressed combined with the scarcity of resources, NIRPS has prioritized some near-term objectives to focus on immediately.

Significantly, NIRPS is developing figures of merit (FOM) to address the current health of the industrial base as well as a periodic survey to keep this assessment current. The Stewardship Team is developing analysis techniques to inform decision makers on the effects of policy, system architecture, and acquisition decisions on the health and sustainability of the industrial base. NIRPS is also actively working to align propulsion technology development plans across agencies, develop and streamline methods for the private sector to access and utilize expertise and facilities in the U.S. Government. NIRPS is building a web-based tool to allow potential users and collaborators a comprehensive inventory of skills, facilities and other capabilities at U.S. Government facilities. NIRPS is closely engaged with the academic community to forecast needs for skilled practitioners in propulsion related fields of study and to ensure that STEM programs will be able to develop personnel with the right knowledge, skills and abilities to ensure that this vital national resource is viable now and in the future.

\section{2012 NDAA Section 1095 National Rocket Propulsion Strategy}

The current state of the propulsion industrial base and strategies for maintaining and strengthening the industrial base are issues of national significance. Section 1095 of the National Defense Authorization Act (NDAA) of 
$2012^{21}$, signed by the President on December 31, 2011 requires a National Rocket Propulsion Strategy. In March of 2012, the White House Office of Science and Technology (OSTP) tasked NIRPS to lead in the development of a strategy and the subsequent required study. This tasking demonstrates OSTP's confidence in NIRPS's mission to coordinate and address propulsion issues on a national level. The study must address the previously mentioned challenges in the rocket propulsion industrial base, and requires an intra-agency task force to ensure each government stakeholder is represented in the study. This unprecedented cooperation aligns with NIRPS's mission to foster a vibrant rocket propulsion community that provides reliable and affordable propulsion systems for the nation's defense, civil, and commercial needs.

\section{Conclusion}

Numerous public and government studies over the past decade point out the need for a focused, multi-organization approach to ensure the continuing availability, viability and competiveness of the U.S. propulsion industrial base. The nation's rocket propulsion industry is in an increasingly precarious position that, if worsened, will adversely affect national security, space exploration, economic growth, and education. While several forums have worked to resolve some of these issues, there has not yet been a coordinated national effort to maintain and strengthen the propulsion industrial base. NIRPS is an effective and responsive solution to this problem.

NIRPS planning discussions currently include 167 participants representing 50 organizations, with more joining weekly. By sector, the NIRPS team includes 9 government organizations, 37industry organizations, and 4 academic organizations. Recently, the NIRPS team analyzed over 40 reports regarding the health of the propulsion industry base and used this information to develop the organization and priorities of the Institute. Stakeholders and team members achieved consensus on the "Grand Challenges" facing in the industry and developed strategies and action plans to address these challenges. Additionally, NIRPS is currently working to coordinate an intra-agency response to Section 1095 of the 2012 NDAA.

NIRPS is still a work in progress and is proceeding on two parallel paths. The first path is establishing the Institute as a national entity with active participation from the entire propulsion community and affected government agencies. The NIRPS leadership team is currently developing a governance structure, defining formal agreements across the U.S. Government and engaging in the budget planning process . The second path will ensure that NIRPS is executing the near-term objectives to address current needs that have been outlined in this paper. NIRPS will continue to coordinate efforts to address the challenges facing the propulsion industrial base in the future. As a new and innovative initiative, the Institute will serve a vital role as a multi-agency organization that policymakers, developers and users can rely on for comprehensive information about the state of technology, infrastructure, and other issues affecting the propulsion industry.

\section{Acknowledgments}

\section{References}

\footnotetext{
${ }^{1}$ Department of Defense and Office of the Director of National Intelligence. National Security Space Strategy. Washington, DC: 2011.

${ }^{2}$ National Space Strategy of the United States of America. Washington, DC: 2010.

${ }^{3}$ National Aeronautics and Space Administration Authorization Act of 2010. Washington DC, 2010.

4-Jim Maser (President, Pratt \& Whitney Rocketdyne) Testimony on A Review of NASA's Exploration Program in Transition: Issues for Congress and Industry before the House Committee on Science, Space and Technology, Subcommittee on Space and Aeronautics. Washington, DC: 30 March 2011.

${ }^{5}$ Office of the Undersecretary of Defense. Annual Industrial Capabilities Report to Congress. Washington, DC: May 2010.

${ }^{6}$ John P. Holdren, Director: Office of Science and Technology Policy. Letter to Congress on Space Launch Propulsion. Washington, DC: 22 December 2009.

${ }^{7}$ Robert M. Read (Office of the Undersecretary of Defense). Solid Rocket Motor (SRM) Congressional Interest. Report to Congress. Washington, DC: December 2009.
} 
${ }^{8}$ Loren Thompson. Reversing Industrial Decline: A Role For The Defense Budget. Lexington Institute. Arlington, Virginia. August 2009.

${ }_{9}^{9}$ Aerospace Industries Association. The Unseen Cost: Industrial Base Consequences of Defense Strategy Choices - A Special Report. Arlington, Virginia: July 2009.

${ }^{10}$ Institute for Defense Analysis. Leadership, Management, and Organization for National Security Space: Report to Congress of the Independent Assessment Panel on the Organization and Management of National Security Space. Arlington, Virginia: July 2008.

${ }^{11}$ Government Accountability Office. Department of Defense: A Department Wide Framework to Identify and Report Gaps in the Defense Supplier Base Is Needed. Washington, DC: October 2008.

12 Office of the Under Secretary of Defense For Acquisition, Technology, and Logistics. Creating an Effective National Security Industrial Base for the 21st Century: An Action Plan to Address the Coming Crisis. Washington, DC: July 2008.

${ }^{13}$ Center for Strategic \& International Studies. Briefing of the Working Group on the Health of the U.S. Space Industrial Base and the Impact of Export Controls. Washington, DC: February 2008.

${ }^{14}$ United States Air Force. Defense Industrial Base Assessment: US Space Industry Final Report. Dayton, Ohio: 31 August 2007.

${ }^{15}$ LTC John L. Thurman (Office of the Secretary of Defense, Cost Analysis Improvement Group). National Security Space Industrial Base Study. Washington, DC: 15 February 2006.

${ }^{16}$ Government Accountability Office. Space Acquisitions: DOD Needs to Take More Action to Address Unrealistic Initial Cost Estimates of Space Systems. Washington, DC: November 2006.

${ }^{17}$ Eric W. Davis (Air Force Research Laboratory). Advanced Propulsion Study. Edwards AFB, CA: September 2004.

${ }^{18}$ Office of the Undersecretary of Defense. Report of the Defense Science Board/Air Force Scientific Advisory Board Joint Task Force on Acquisition of National Security Space Programs. Washington, DC: May 2003.

${ }^{19}$ Aerospace Industries Association. 2008 Year End Review and 2009 Forecast - An Analysis. Arlington, Virginia: 2008.

${ }^{20}$ John Birkler, et al. (RAND National Defense Research Institute). Competition and Innovation in the U.S. Fixed-Wing Military Aircraft Industry. Santa Monica, California: 2003

${ }^{21}$ National Defense Authorization Act for Fiscal Year 2012. Washington DC: 2011 